\title{
Growth Performance of Corn as Influenced by the Combined Application of Organic and Inorganic Fertilizers in a Marginal Upland Soil
}

\author{
Suzette B. Lina, Deejay S. Maranguit, Victor B. Asio, Jessie R. \\ Sabijon, Kier Lambert B. Demain and Ariel B. Bolledo
}

Department of Agronomy and Soil Science, Visayas State University, Visca, Baybay City, Leyte 6521-A

\section{ABSTRACT}

Development of an integrated nutrient management strategy is needed to enhance soil quality and increase crop yields in the marginal uplands of Eastern Visayas. Due to very poor soil condition, a field fertilizer experiment using the combined application of organic and inorganic fertilizers was conducted in Inopacan, Leyte, to assess the growth performance of corn plants. The six treatment combinations used in this study were the following: $\mathrm{T}_{1}$ (no fertilizer added); $\mathrm{T}_{2}$ (National recommendation for corn at 90-60-60 kg $\mathrm{N}, \mathrm{P}_{2} \mathrm{O}_{5}, \mathrm{~K}_{2} \mathrm{O}$ ha $^{-1}$ ); $\mathrm{T}_{3}$ (chicken dung at 15 tons ha ${ }^{-1}$ ); $\mathrm{T}_{4}$ (vermicast at 15 tons ha $\left.{ }^{1}\right) ; \mathrm{T}_{5}\left(1 / 2\right.$ of inorganic + chicken dung at 7.5 tons ha $\left.^{-1}\right)$ and $\mathrm{T}_{6}(1 / 2$ of inorganic + vermicast at 7.5 tons $\mathrm{ha}^{-1}$ ). Generally, application of organic fertilizer significantly increased soil $\mathrm{pH}$, organic matter and total nitrogen. In addition, the treatments significantly increased, plant height, ear length, number of grains per ear, weight of 1,000 seeds, fresh stover yield, and grain yield of corn Corn plants in plots applied with fertilizer following $\mathrm{T}_{2}$ (National Recommendation for corn at 90-60-60 kg N, $\mathrm{P}_{2} \mathrm{O}_{5}, \mathrm{~K}_{2} \mathrm{O}$ ha $^{-1}$ ) and $\mathrm{T}_{5}(1 / 2$ of inorganic + chicken dung at 7.5 tons ha ${ }^{-1}$ ) grew taller and developed larger ears with more kernels per ear and heavier 1,000 seeds which resulted to higher grain yield. However, using inorganic fertilizer alone had the same effect on ear length, number of kernels per ear of those corn plants applied with combination of either chicken dung or vermicast and one-half of inorganic fertilizers. Plants in control plots and those amended with vermicast alone showed the least growth responses.

Keywords: Marginal upland soil, degraded soil, organic and inorganic fertilizer.

Correspondence : S.B. Lina Address: Department of Agronomy and Soil Science, Visayas State University, Visca, Baybay City, Leyte6521-A Email: sblina510@yahoo.com DOI: $10.32945 /$ atr36s2.2014 


\section{INTRODUCTION}

Several problems are encountered by the farmers in marginal areas of Eastern Visayas. These problems include very low crop productivity due to low inherent soil fertility, lack of resources, inadequate supply of water, lack of appropriate technologies, improper water and soil conservation management, high cost of fertilizer, and soil degradation. Marginal upland farmers are confronted with several disadvantages that make their lands "marginal" for agriculture. To address this issue, sustainable soil nutrientenhancing strategies such as the integrated nutrient management (INM) which involves the proper use and management of inorganic and organic nutrient sources in production systems (Janssen, 1993) can be applied.

INM implies the maintenance or adjustment of soil fertility and plant nutrient supply to an optimum level to sustain the desired crop productivity and to minimize nutrient losses. It is achieved through efficient management of all nutrient sources. Nutrient sources for growing plants include soil minerals and decomposing soil organic matter, mineral and synthetic fertilizers, animal manures and composts, by-products and wastes, plant residues and biological N-fixation (Singh et al., 2002). One of the primary objectives of INM is to create and combine both old and new methods of nutrient management into ecologically sound and economically viable farming systems that utilize available organic and inorganic sources of nutrients in a judicious and efficient way.

Upland areas are planted to different agricultural crops such as cassava, sweet potato, corn, banana, coconut, upland rice, and other crops. In marginal uplands, corn is second to rice as the most important crop with one-third of Filipino farmers, or 1.8 million, depending on corn as their major source of livelihood. Out of the 1.6 million hectares planted to corn in the Philippines, $75 \%$ are in marginal uplands. Large quantities of corn are consumed in North and Eastern Luzon, Central and Eastern Visayas, and Northern and Western Mindanao. Corn is a staple food in periods of rice shortage, especially for people living in marginal areas and about $15 \%$ of the Filipinos living in rural areas of the Philippines. The grits obtained after milling the grains are boiled as a substitute for rice. Of all the cereal grains, corn is highly valued due to its multifarious uses, aside from having higher amount of vitamins, proteins, and carbohydrates (PCARR, 1996).

Total land area planted to corn was highest in 1990 at 3.8 million hectares, but declined at 1.9\% per year from 1985 to 2001 (Gonzales and Lapiña, 2003). The continued increase in human population 
led to the decrease in prime agricultural land areas for corn cultivation which resulted in the decline in crop production and thus corn-supply shortage. With this problem, the primary goal of the government is to improve soil quality for better crop production. Fertilizer application is considered the most common and conventional farm practice in augmenting and overcoming the limitation of infertile soil to supply the adequate nutrients for better growth and higher yields of the crops (Zamora, 2007).

Fertilizers are either of inorganic or organic form. The use of inorganic fertilizers is the most popular and convenient way to improve soil fertility. Inorganic fertilizers are used in modern agriculture to correct known plant nutrient deficiencies, provide high levels of nutrition and improve crop quality. However, inorganic fertilizers are generally expensive and unaffordable for many of the farmers (Bumb, 1994; Gerner et al., 1995). Consequently, there is a serious negative balance in nutrient budgets of soils in the country posing a major constraint to sustainable soil management for increasing crop growth and yield. Ironically, there is a large amount of organic waste that can be turned into fertilizers for crop production at low cost. Ayineh (2011) reported the importance of using organic wastes that are cheap, readily available, and environmentally friendly. Chicken manure and vermicast are among the major organic fertilizers worthy as source of nutrients either alone or in combination with inorganic fertilizer. Many studies have also demonstrated that application of manure produces crop yields equivalent or superior to those obtained using chemical fertilizers (Xie and MacKenzie, 1986; Motavalli et al., 1989). Leonard (1986) quoted $1.1 \% \mathrm{~N}, 1.1 \% \mathrm{P}_{2} \mathrm{O}_{5}$ and $0.5 \mathrm{~K}_{2} \mathrm{O}$ for poultry manure at $70 \%$ moisture content. Moreover, vermicast is rich in mineral nutrients, vitamins, plant growth hormones, proteins and enzymes, and is therefore, considered as a very good organic fertilizer and soil conditioner (Prabha et al., 2005). Early studies showed that vermicompost application resulted in improved crop growth and increased nitrogen $(\mathrm{N})$ and phosphorus $(\mathrm{P})$ leading to increase in yield of crops (Arancon et al., 2004). Other experiments demonstrated that addition of 5, 10, and $15 \mathrm{tha}^{-1}$ vermicompost in soil had significant positive effect on uptake of element nutrients such as P, K, Fe and Zn (Azarmi et al., 2008). Aziz et al., (2010) suggested that integrated use of organic manure with chemical fertilizers would be a better and practical approach to sustain soil fertility and productivity. Moreover, emerging evidence indicates that integrated soil fertility management involving judicious 
use of combinations of organic and inorganic resources is a feasible approach to overcome soil fertility constraints (Abedi et al., 2010).

Several studies had been carried out on the combined effects of organic and inorganic fertilizers on the growth and yield of maize (Mbah and Onweremadu, 2009). However, in Leyte island, only few upland farmers are using the INM approach and there is also limited published data available because the efficacy of soil amendments are said to be site specific.

With a grant from the Commission on Higher Education - Philippine Higher Education Research Network (CHED - PHERNET), a project on Soil and Environmental Quality Enhancement in Marginal Uplands (SEQUEMU) has been implemented to focus on the development of an integrated nutrient management strategy to enhance soil quality and increase crop yields in the marginal uplands of Eastern Visayas. This component study was conducted to assess the growth performance of corn grown in a marginal soil as influenced by the combined application of organic and inorganic fertilizer and to evaluate the effects of combined application of organic on some soil chemical properties.

\section{MATERIALS AND METHOD}

\section{Site Selection, Description and Land Preparation}

Selection of the study site was based on the characteristics of marginal uplands such as hilly, acidic, prone to drought, low soil fertility level and dominated by grassland vegetative cover. The study was conducted in Sitio Batuan, Brgy. Linao, Inopacan, Leyte which is about $4 \mathrm{~km}$ east of Inopacan town with an elevation of $250 \mathrm{~m}$ asl. The total area used for this study was $620 \mathrm{~m}^{2}$ with a clay loam soil type having low soil $\mathrm{pH}$ (5.0), moderate amount of soil organic matter (2.79\%), and low total $\mathrm{N}(0.164 \%)$. Immediately after site selection, the area was plowed and harrowed twice at weekly interval. Immediately after last harrowing, furrows were made at a distance of $75 \mathrm{~cm}$ apart immediately after the last harrowing.

\section{Experimental Design and Lay-out}

The treatments used in the study were designated as follows: $\mathrm{T}_{1}=$ No fertilizer added; $\mathrm{T}_{2}=$ National Recommendation rate $\left(90-60-60 \mathrm{~N}, \mathrm{P}_{2} \mathrm{O}_{5}\right.$, $\left.\mathrm{K}_{2} \mathrm{O} \mathrm{Kg} \mathrm{ha}{ }^{-1}\right) ; \mathrm{T}_{3}=$ Chicken Dung $\left(15 \mathrm{tha}^{-1}\right) ; \mathrm{T}_{4}=\operatorname{Vermicast}\left(15 \mathrm{tha}^{-1}\right) ; \mathrm{T}_{5}=1 / 2$ 


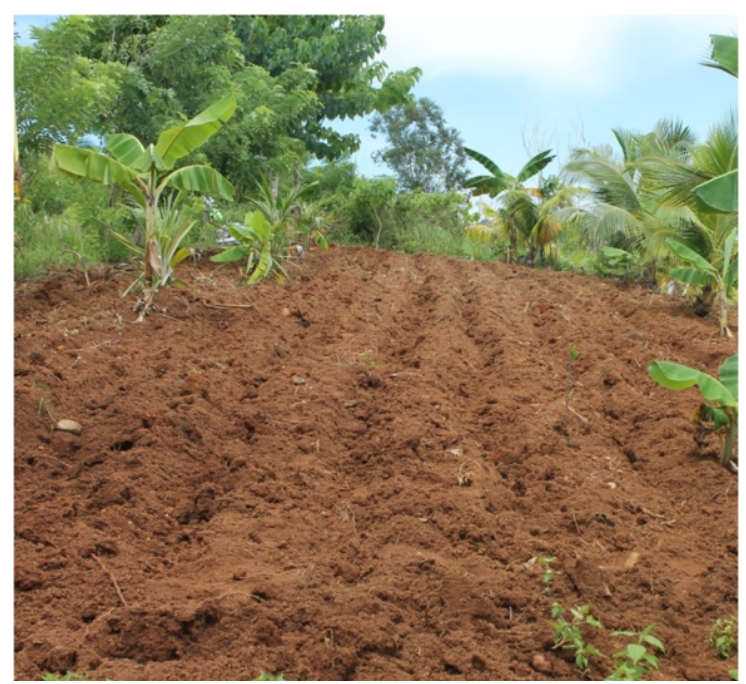

Fig. 1. Photo shows the experiment area after farming operation.

RR + 1/2 Chicken Dung ( 7.5 tha $\left.^{-1}\right) ; T_{6}=1 / 2 R R+1 / 2$ Vermicast $\left(7.5\right.$ t ha $\left.^{-1}\right)$. The experimental area was laid - out in randomized complete block design (RCBD) with six treatments and replicated three times. Each replication was divided into six plots each plot measured $5 \mathrm{~m} \times 4.25 \mathrm{~m}\left(22.25 \mathrm{~m}^{2}\right)$ with seven rows. Both replication and treatment plots were separated by $1 \mathrm{~m}$ alleyways, to facilitate farm operations and management as well as data gathering.

\section{Fertilizer Application, Planting and Care Management}

Application of fertilizer was done after land preparation. Organic fertilizers (chicken dung and vermicast) and inorganic fertilizers (urea, solophos, and muriate of potash) were used as soil amendments. The amounts of organic fertilizers were adjusted on air-dry weight basis. Both organic and inorganic fertilizers were applied in furrows per plot. Based on the designated treatment, corn seeds (IPB Var. 6) were sown in furrows at a distance of $75 \mathrm{~cm}$ between rows and $50 \mathrm{~cm}$ between hills at 2 to 3 seeds/hill. The same procedures were done in the second cropping. Corn plants were thinned to 2 plants per hill one week after sowing while replanting of missing hills was done one week after seedling emergence to 
meet the desired plant population. Weeds were controlled by hand weeding. Hilling-up was also done manually in each treatment plot for better stability and anchorage of plants. Insect pests and diseases were controlled and monitored by the Pest Management Staff of the project using visual observation method, sweep net, pan trap, malaise trap and laboratory analysis.

\section{Harvesting and Data Gathering}

Gathering of data on the agronomic characteristics of the plant was done throughout the vegetative and reproductive stage of the corn plants during wet and dry seasons. The agronomic characteristics and yield and yield components gathered included the number of days from sowing to tasseling, silking and maturity; plant height $(\mathrm{cm})$, fresh stover yield $\left(\mathrm{t} \mathrm{ha}^{-1}\right)$, ear length (cm); weight of 1000 seeds $(\mathrm{g})$ and grain yield $\left(\mathrm{t} \mathrm{ha} \mathrm{C}^{-1}\right)$. When about $90 \%$ of the corn plants had reached maturity as indicated by the change in color of the husks and leaves from green to brown, harvesting and data gathering of the yield and yield components were done. Only plants in the five inner rows in each treatment plot were harvested excluding the border rows and one end hill in each row. The harvested sample ears were dehusked, shelled, and the grains were sundried before weighing. Sun-drying of grains was done for two to three days to attain the desired moisture content of approximately $14 \%$. Right after harvest, corn stovers were cut into small pieces and incorporated into the soil in the experimental area.

\section{Statistical Analysis}

The data obtained were subjected to analysis of variance using Sirichai Statistics Version 6.00. Least significant difference (LSD) value at 5\% level of significance was used for comparison of treatment means by Duncan's Multiple Range Test.

\section{RESULTS AND DISCUSSION}

\section{General Observation}

One week after sowing the seeds, the emergence of corn seedlings were observed to be uniform in all treatments. Differences in plant growth were 
very observable one month later (Fig. 2). Plants in control plots (no fertilizer added) were observed to have a very inferior growth compared to those applied with inorganic and organic fertilizers. Generally, plants applied with combined inorganic and organic fertilizers had better growth performance than those not applied with fertilizer (control) and those with organic fertilizer alone. Application of organic fertilizer either applied alone or in combination with inorganic fertilizer significantly increased soil $\mathrm{pH}$, organic matter and total nitrogen $(\mathrm{N})$.

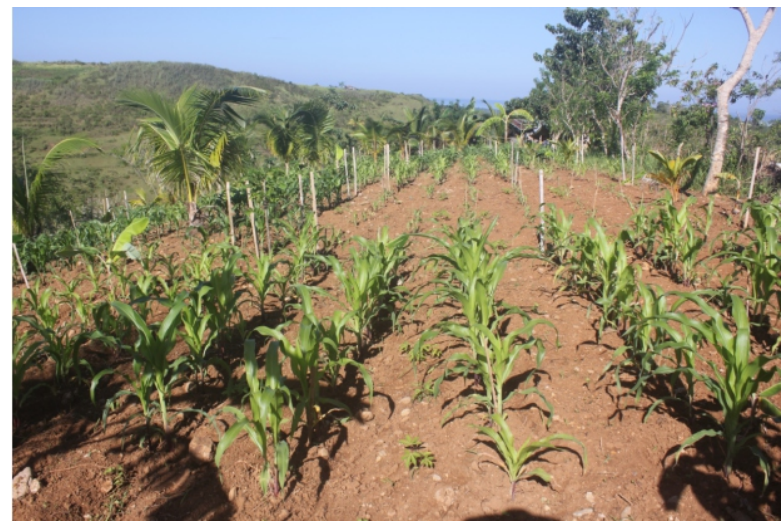

Fig.2a. Stand of corn plants one month after planting. Note the growth of the control plants in the middle of the field and those applied with organic and inorganic fertilizers in the foreground.

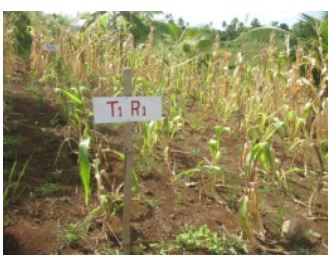

control

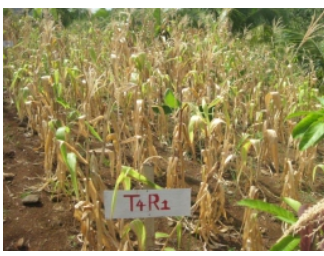

Vermi alone-15 $\mathrm{T}^{\mathrm{h}} \mathrm{p}^{-1}$

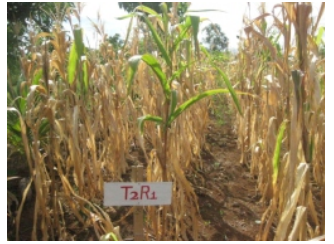

90-60-90 kg NPK

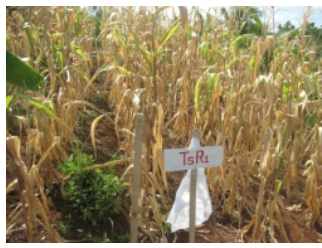

Chicken dung $+1 / 2$ RR

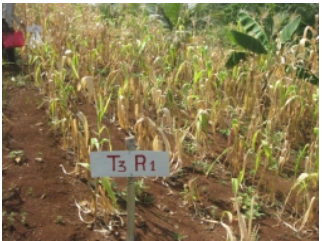

Chicken dung alone-15 $\mathrm{T} \mathrm{ha}^{-1}$

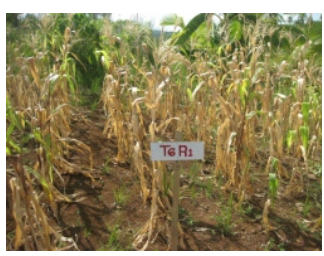

Vermi + 1/2 RR

Fig. 2b. Stand of corn plants before harvest. 


\section{Agronomic Characteristics}

Monthly plant height of corn under different organic and inorganic fertilizer treatments significantly differed (Fig 3). Results indicated that both organic and inorganic fertilizers affected plant height significantly from the early vegetative stage up to maturity. Application of inorganic fertilizer at 90-60-60 kg N, $\mathrm{P}_{2} \mathrm{O}_{5}, \mathrm{~K}_{2} \mathrm{O}$ ha ${ }^{-1}\left(\mathrm{~T}_{2}\right)$ significantly increased plant height. On the other hand, combined application of organic and inorganic fertilizers using either chicken dung or vermicast promoted better plant growth compared to the control plots. The number of days from sowing to taselling, silking, and maturity were also significantly affected by the application of organic and inorganic fertilizers $\left(\mathrm{T}_{2}, \mathrm{~T}_{3}, \mathrm{~T}_{4}\right.$ and $\left.\mathrm{T}_{5}\right)$ compared to the control plots $\left(\mathrm{T}_{1}\right)$ as shown in Table 1 . Corn plants applied with organic fertilizer, either singly or in combination, of either chicken dung or vermicast and $1 / 2$ of the inorganic fertilizer, produced tassel and silk and matured earlier comparable to those applied with inorganic fertilizer alone.

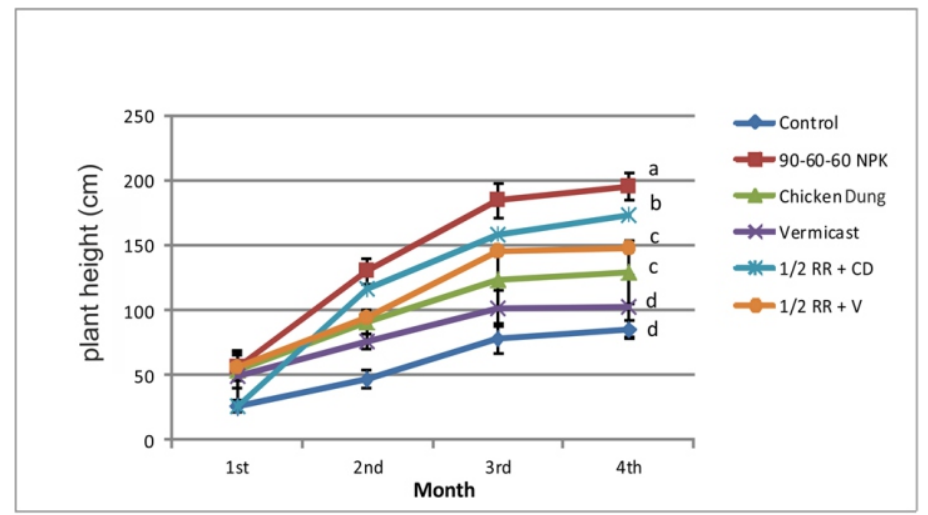

Fig. 3. Monthly plant height $(\mathrm{cm})$ of corn as influenced by application of organic and inorganic fertilizers, alone and in combination in a marginal upland soil.

\section{Yield and yield components}

The productivity of maize largely depends on its nutrient requirement and management particularly that of nitrogen, phosphorus, and potassium (Arunkumar, 2007). Table 2 shows the effect of organic and inorganic fertilizer application on the number of kernels, weight of 1000 seeds and 
ear length. Fertilizer application significantly affected the number of kernels, weight of 1000 seeds, and ear length. Plants applied with inorganic fertilizer $\left(\mathrm{T}_{2}\right)$ and inorganic fertilizer + chicken dung at $7.5 \mathrm{t} \mathrm{ha}^{-1}$ $\left(\mathrm{T}_{5}\right)$ produced the longest ear length $(13 \mathrm{~cm})$ and more number of kernels (236.43) while plants which did not receive fertilizer $\left(\mathrm{T}_{1}\right)$ exhibited the shortes ear length, and the least number of kernels (37.33). The weight of 1000 seeds was also significantly higher with the application of inorganic fertilizer + vermicast at $7.5 \mathrm{t} \mathrm{ha}^{-1}\left(\mathrm{~T}_{6}\right)$. It produced the highest value of $238.67 \mathrm{~g}$ but this was not significantly different from those in $\mathrm{T}_{2}, \mathrm{~T}_{3}, \mathrm{~T}_{4}$ and $\mathrm{T}_{5}$. Plants in the control plots showed the lowest value of 91.67g. On the other hand, fresh stover yield of corn was significantly improved with the application of organic and inorganic fertilizers (Fig. 4). Results implies that application of inorganic fertilizer alone or in combination with organic fertilizer could produce a higher stover yield of corn.

Figure 5, shows the grain yield of corn as affected by fertilizer application. The results indicate that the grain yield of corn per hectare was significantly affected by the application of organic and inorganic fertilizers. It was clearly observed that application of fertilizer, either inorganic or organic resulted to better yield. $\mathrm{T}_{2}$ had the highest grain yield $\left(0.43 \mathrm{t} \mathrm{ha}^{-1}\right)$ followed by $\mathrm{T}_{5}\left(0.41 \mathrm{tha}^{-1}\right) . \mathrm{T}_{1}$ obtained the lowest grain yield $\left(0.07 \mathrm{t} \mathrm{ha}^{-1}\right)$. However, all these values were significantly lower than the National average corn yield of 3.5 tons ha $^{-1}$.

Table 1. Agronomic characteristics of corn as influenced by application of organic and inorganicfertilizers

\begin{tabular}{llll}
\hline \multirow{2}{*}{ Treatments } & \multicolumn{3}{l}{ Number of days from sowing to } \\
& Taselling & Silking & Maturity \\
\hline $\mathrm{T}_{1}-$ Control (without application) & $54.33 \mathrm{a}$ & $63.67 \mathrm{a}$ & $100.00 \mathrm{a}$ \\
$\mathrm{T}_{2}-\left(90-60-60 \mathrm{~N}, \mathrm{P}_{2} \mathrm{O}_{5}, \mathrm{~K}_{2} \mathrm{O} \mathrm{kg} \mathrm{ha}{ }^{-1}\right)$ & $46.67 \mathrm{c}$ & $55.67 \mathrm{c}$ & $95.00 \mathrm{c}$ \\
$\mathrm{T} 3-$ Chicken Dung at $\left(15 \mathrm{tha}^{-1}\right)$ & $47.00 \mathrm{c}$ & $56.67 \mathrm{bc}$ & $96.33 \mathrm{bc}$ \\
$\mathrm{T} 4-$ Vermicast at $\left(15 \mathrm{t} \mathrm{ha}^{-1}\right)$ & $49.33 \mathrm{~b}$ & $58.33 \mathrm{~b}$ & $99.33 \mathrm{a}$ \\
$\mathrm{T} 5-1 / 2 \mathrm{RR}+$ Chicken dung at $\left(7.5 \mathrm{t} \mathrm{ha}^{-1}\right)$ & $46.00 \mathrm{c}$ & $55.33 \mathrm{c}$ & $95.33 \mathrm{c}$ \\
$\mathrm{T} 6-1 / 2 \mathrm{RR}+$ Vermicast at $\left(7.5 \mathrm{t} \mathrm{ha}^{-1}\right)$ & $47.33 \mathrm{bc}$ & $57.00 \mathrm{bc}$ & $98.00 \mathrm{ab}$ \\
\hline $\mathrm{CV}(\%)$ & 2.40 & 1.66 & 1.24 \\
\hline
\end{tabular}

Means not sharing letter in common differ significantly at $0.05 \%$ probability level by Duncan's Multiple Range Test. 
Table 2. Yield and yield components of corn as influenced by the application of organic and inorganic fertilizers in a marginal upland soil.

\begin{tabular}{|c|c|c|c|c|c|}
\hline Treatments & Ear Length (cm) & $\begin{array}{c}\text { No.of Kernels } \\
\text { per ear }\end{array}$ & $\begin{array}{l}\text { Weight of } \\
1000 \text { seeds }\end{array}$ & $\begin{array}{l}\text { Stover Yield } \\
\left(\text { tons } \mathrm{ha}^{-1}\right)\end{array}$ & $\begin{array}{c}\text { Grain yield } \\
\text { (tons ha-1) }\end{array}$ \\
\hline $\mathrm{T}_{1}-$ Control (without application) & $5.61 \mathrm{c}$ & $41.20 \mathrm{~cd}$ & $91.67 \mathrm{bc}$ & $0.72 \mathrm{~d}$ & $0.07 \mathrm{~b}$ \\
\hline T3 - Chicken Dung (15 t ha $\left.{ }^{-1}\right)$ & $7.86 \mathrm{bc}$ & $73.27 \mathrm{c}$ & $220.33 a$ & $3.10 \mathrm{c}$ & $0.36 \mathrm{a}$ \\
\hline $\mathrm{T} 5-1 / 2 \mathrm{RR}+$ Chicken dung $\left(7.5 \mathrm{t} \mathrm{ha}^{-1}\right)$ & $11.48 \mathrm{a}$ & $216.20 \mathrm{a}$ & $226.00 \mathrm{a}$ & $5.41 b$ & $0.41 \mathrm{a}$ \\
\hline T6 $-1 / 2 \mathrm{RR}+$ Vermicast $\left(7.5 \mathrm{t} \mathrm{ha}^{-1}\right)$ & $9.24 b$ & $126.50 b$ & $238.67 \mathrm{a}$ & $3.58 \mathrm{bc}$ & $0.34 \mathrm{a}$ \\
\hline CV (\%) & 11.67 & 16.29 & 23.51 & 28.39 & 25.51 \\
\hline
\end{tabular}

Means not sharing letter in common differ significantly at $0.05 \%$ probability level by Duncan's Multiple Range Test.

No significant difference $0.07 \mathrm{~b}$ and $0.14 \mathrm{~b}, 0.43 \mathrm{a}, 0.36 \mathrm{a}$ and $0.41 \mathrm{a}, 0.34 \mathrm{a}$ no significant difference. 
The findings of the present study agree with that of Makinde et al., (2001a) who reported that the sole application of inorganic fertilizer or mixture of organic and inorganic fertilizer significantly increased corn yield in marginal areas. In a similar study, Zhao et al. (2009) found that application of farmyard manure combined with chemical fertilizer management resulted to higher increase in maize yield compared with those under unfertilized treatment. Kimeto et al. (2004) also found that a combination of both organic and inorganic nutrient sources gave higher maize yield than organic fertilizer alone.

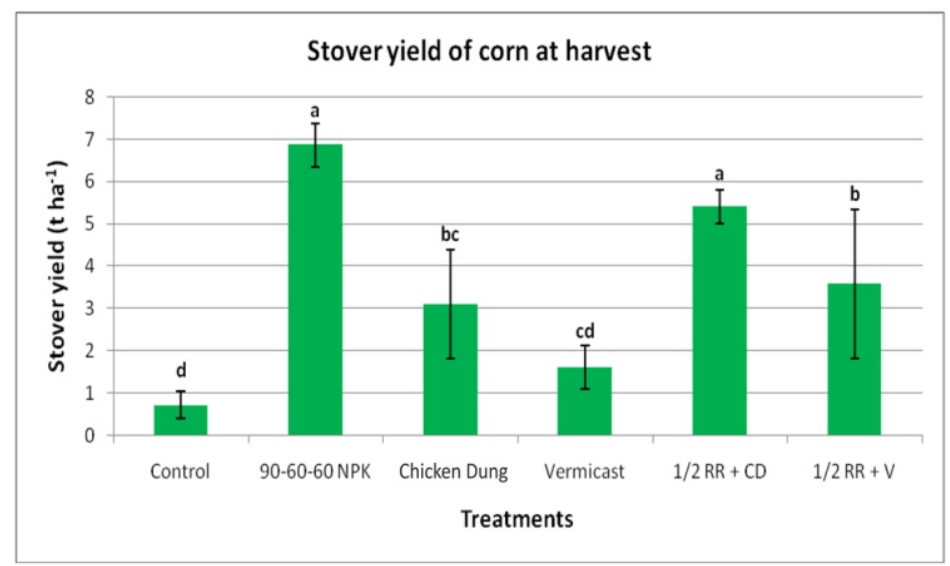

Figure 4. Fresh stover yield $\left(\mathrm{t} \mathrm{ha}^{-1}\right)$ of corn as influenced by application of organic and inorganic fertilizers in a marginal upland soil

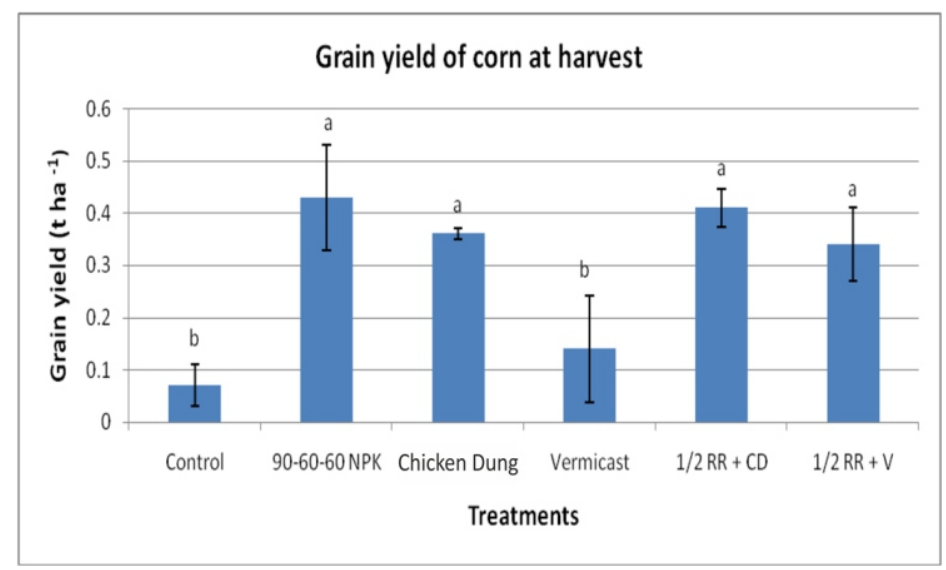

Figure 5. Grain yield ( $\left.\mathrm{t} \mathrm{ha}^{-1}\right)$ of corn at harvest as influenced by application of organic and inorganic fertilizers in a marginal upland soil 


\section{CONCLUSION}

Results of the study revealed that application of organic fertilizer significantly increased soil $\mathrm{pH}$, organic matter, and total nitrogen. Among the agronomic parameters gathered, plant height, ear length, number of grains per ear, weight of 1,000 seeds, fresh stover yield, and grain yield of corn grown in degraded soil were significantly increased by the application of organic and inorganic fertilizers. Moreover, corn plants in plots applied with fertilizer following $\mathrm{T}_{2}$ (National Recommendation for corn at 90-60$60 \mathrm{~kg} \mathrm{~N}, \mathrm{P}_{2} \mathrm{O}_{5}, \mathrm{~K}_{2} \mathrm{O}$ ha $^{-1}$ ) grew taller and developed larger ears with more kernels per ear and heavier 1,000 seeds which resulted in higher grain yield. However, using inorganic fertilizer alone had the same effect on ear length and number of kernels per ear of corn plants applied with combination of either chicken dung or vermicast and one-half of inorganic fertilizers. On the other hand, plants in control plots and those amended with vermicast alone showed the least growth responses.

\section{REFERENCES}

ABEDI, T., A. ALEMZADEH, and S.A. KAZEMELNI. 2010. Effect of organic and inorganic fertilizers on grain yield and protein banding pattern of wheat. AustJCrop Sci 4:384-389.

ARANCON, N.Q., C.I. EDWARDS, P. BIERMAN, C. WELCH, and T.D. METZGER. 2004. Influences of vermicomposts on field strawberries: 1 . Effect on growth and Yields. Bioresour. Technol., 93:145 -153.

AYINEH L.S. 2011. Integrated Plant Nutrient management: A panacea for Sustainable Crop production in Nigeria.

AZARMI, R., P. SHARIFI, and M.R. SATARI. 2008. Effect of vermicompost on growth, yield and nutrition status of tomato (Lycopersicunesculentum) In Press.

AZIZ, T., S. ULLAH, A. SATTAR, M. NASIM, M. FAROOQ and M.M. KHAN. 2010. Nutrient availability and maize (Zea mays L.) growth in soil amended with organic manures. Int. J. agric. Biol., 12:621-624. 
BUMB, B.I. 1994. World nitrogen supply and demand: An overview. In Bacon, P. E. (ed) Nitrogen Fertilization and The Environment. Marcel Dekker Inc. New York, USA.

GERNER H., E.O. ASANTE, E. OWUSU-BENNOAH and K. MARFO. 1995.Ghanna fertilizer privatization scheme: Private Sector Roles and Public Sector responsibilities in meeting needs of farmers. IFDC-Africa, Lome, Togo.

GONZALES, L.A., and G.F. LAPIÑA. 2003. The Philippine Corn Industry in global Transition: Some Strategic and policy Directions. Paper presented during the First Philippine Corn Annual Symposium and Planning Workshop, January 15-17, 2003. Monte Vista Resort Calamba Laguna, Philippines.

JANSSEN, B.H. 1993. Integrated nutrient management: the use of organic and mineral fertilizers. In: The Role of Plant Nutrients for Sustainable Crop Production in Sub-Saharan Africa, H. van Reuler and W.H. Prins (Eds.). Ponsen and Looijen, Wageningen, The Netherlands, pp. 89-105.

KIMETO, J.M., D.N. MUGENDI, C.A. PALM, P.K. MUTUO, C. GACHENGO, A. BATIONO, S. NANDWA, and J.B. KUNGU. 2004. Nitrogen fertilizer equivalencies of organics and differing quality and optimum combination with inorganic nitrogen source in central Kenya. Nutr Cycl Agroecosyst 68:127-135.

LEONARD, D. 1986. Soil, Crop, and Fertilizer Use: A Field Manual for Development Workers. Under contract with Peace Corps. $4^{\text {th }}$ edition revised and expanded. United State Peace Corps. Information collection and exchange. Reprint R0008.

MAKINDE, E.A., A. AGBOOLA and F.I. OLUWATOYINBO. 2001. The effects of organic and inorganic fertilizers on the growth and yield of maize in a maize/melon intercrop. Moor Journal of Agricultural Research 2:15-20.

MBAH C.N. and E.U. ONWEREMADU. 2009. effect of organic and mineral fertilizer inputs on soil and maize garin yield in an acid ultisol in abakaliki-south eastern Nigeria. American-Eurasian Journal of Agronomy 2 (1): 07-12, 2009.ISSN 1995-896X IDOSIPublicatios. 
MOTAVALLI P.P., K.A. KELLING, and J.C. CONVERSE. 1989. First - year nutrient availability from injected dairy manure. J. Environ. Qual. 18: $180-185$.

PCARR. 1996. The Philippines Recommends for Corn. Philippine Council for Agric. Research Los Baños, Laguna.106 pp.

PRABHA, L.M., and I.A. JAYRAAJ. 2005. Macro and Micronutrient changes in vermicomposting of vegetable wastes using Eudriluseugeniae. South Asian Journal of Socio-Political Studies, 2, 129-130,156.

SINGH, R.B., P. KUMAR, and T. WOODHEAD. 2002. Smallholder Farmers in India: Food Security and Agricultural Policy. RAP Publication 2002/2003. Bangkok, Thailand, FAO.

XIE, R.J. and A.F. MACKENZIE. 1986. Urea and manure effects on soil nitrogen and corn dry matter yield. Soil Sci. Soc. Am.J. 50: 1504 -1509.

ZAMORA, R.F. 2007. Fertilizer and water management for lowland rice production Undergrad Thesis ViSCA, Baybay, Leyte. Pp. 51.

ZHAO, Y., P. WANG, J. LI, Y. CHEN, X. YING and S. LIU. 2009.The effect of two organic manures on soil properties and crop yield on a temperate calcareous soil under a wheat-maize cropping system. Eur J Argon 31: 36-42. 